\title{
Antimicrobial and antioxidant activities of salt stress callus of Brinjal (Solanum melongena L.)
}

\author{
K. Kalimuthu ${ }^{1 *}$, A.Vanitha ${ }^{1}$, Vajjiram Chinnadurai ${ }^{1}$, R. Prabakaran ${ }^{2}$ \\ ${ }^{1}$ Plant Tissue Culture Division, PG and Research Department of Botany, Government Arts College (Autonomous), \\ Coimbatore-641018, India. \\ K_kalimuthu@rediffmail.com, avanithagreen@gmail.com, chinnaa.v1987@gmail.com. \\ ${ }^{1}$ Department of Botany, PSG College of Arts and Science, Coimbatore-641014, India. \\ raju.prabakaran@gmail.com.
}

\begin{abstract}
Ethanolic and methanolic salt stress callus extracts of Solanum melongena $L$. were tested for in vitro antimicrobial and free radical scavenging assayssuch as DPPH (1,1-diphenyl-2-picrylhydrazyl) and ABTS $^{+}(2,2$ 'Azinobis (3-ethyl benzo-thizoline-6-sulfonic acid). In both the extracts the zone of inhibition is higher in Escherichia coli, Klebsiella pneumonia, Staphylococcus aureusand Streptococcus pyogenesat 90 $\mu l$ concentration against the control. The antifungal activity of these extracts also the zone of inhibition is higher at $90 \mu \mathrm{l}$ concentration against the control. The DPPH activity of different concentration of solvent extracts $(1 \mathrm{mg} / \mathrm{ml}$ to $5 \mathrm{mg} / \mathrm{ml}$ ) along with standard ascorbic acid among the five different concentration (50 $\mu \mathrm{g} / \mathrm{ml}$ to $250 \mu \mathrm{g} / \mathrm{ml}$ ) of extracts tested, the higher percentage of inhibition was observed in $250 \mu \mathrm{g} / \mathrm{ml}$ of methanol extract followed by ethanolic extract against the standard ascorbic acid. In $A B T S^{+}$activity the absorbance was increased with the increasing concentrations of both methanolic and ethanolic callus extracts.
\end{abstract}

Keywords-Antioxidant, , Inhibition, In vitro, Stress tolerant callus, Solanum melongena.

\section{INTRODUCTION}

Plants have been an important source of medicine, mainly on traditional remedies for thousands of years [1]. The bioactive substances present in plants have wide range of biological functions including antioxidant and antimicrobial activities [2,3]. Environmental stresses strongly influence plant growth and development. Through biotechnology tools, the production of virus free plants, salinity tolerance, herbicide resistance, frost resistant is passible [4]. These stress agents influence on biosynthesis of secondary metabolites and resulting in considerable fluctuations in quality and quantity. The composition of secondary product may vary within the same plant. Generally, the efficacy of the plant depend on the combined effect of plant metabolites rather than the few fractions separated from the plant. This leads to select a plant S. melongena $\mathrm{L}$. for the changes in biochemical activities under salt stress.

Brinjal or Eggplant (Solanum melongena L.) is an important vegetable crop belong to the family Solanaceae. The family contain 75 genera and around 2000 species. In India, it is represented by 21 genera and 70 species. Brinjal is an herbaceous perennial plant but cultivated as annual. In popular medicine, brinjal is indicated for the treatment of several diseases, including diabetes, arthritis, asthma and bronchitis. In addition, that brinjal extracts have a significant effect in reducing blood and liver cholesterol in humans [5,6] and adult rats [7]. Nasunin, a major component of anthocyanin pigment of brinjal, has been shown to inhibit lipid peroxidation [8]. Free radical scavenging and iron chelating activities of nasunin were demonstrated by electron spin resonance [9]. Furthermore, anti-mutagenic activity of pheophytin components from brinjal fruit extracts acting against several chemical mutagens was reported [10]. The unripe fruit of brinjal is primarily used as a cooking vegetable for the various dishes in different regions of the World. It has much potential as raw material in pickle making and dehydration industries $[5,6]$.

Understanding the importance of salt tolerance in crop plants such as brinjal, the present work is to focus on the production of salinity tolerance brinjal callus through in vitro culture technology and to analyze antioxidant and antimicrobial activity of ethanol and methanol extracts of in vitro salt callus.

\section{MATERIALS AND METHODS}

2.1 Preparation of salt callus extracts

The leaf derived 40 days old 20 gram of powdered brinjal salt callus was successively extracted using $50 \mathrm{ml}$ of ethanol and methanol by using the Soxhlet extractor for 8$10 \mathrm{hrs}$ [11]. The extract was filtered through Whatmann No.1 filter paper to remove all undissolved matter including cellular materials and other constitutions that are insoluble in the extraction solvent. The respective extracts were concentrated in vacuum (Rota vapor) and 
the residues from the ethanol and methanol extracts were weighed and stored in sealed vials in a freezer until tested.

\subsection{Antimicrobial activity}

\subsubsection{Test microorganisms}

The test organisms used were clinical isolates viz., Streptococcus pyogenes, Staphylococcus aureus, Escherichia coli and Klebsiella pneumoniaeand the human fungal pathogens like Candida albicans and Trichoderma viride, which were obtained from Department of Microbiology, Hindusthan College of Arts and Science Coimbatore. The bacterial and the fungal cultures were maintained on nutrient agar medium at $37^{\circ} \mathrm{C}$ and potato dextrose agar (PDA) medium at $28^{\circ} \mathrm{C}$ respectively.

\subsubsection{Preparation of Inoculum}

The gram positive bacteria Streptococcus pyogenes, Staphylococcus aureus and gram negative bacteria E. coli and Klebsiella pneumoniae were pre-cultured in nutrient broth overnight in a rotary shaker at $37^{\circ} \mathrm{C}$, centrifuged at $10,000 \mathrm{rpm}$ for $5 \mathrm{~min}$, pellet was suspended in double distilled water and the cell density was standardized spectrophotometrically $\left(\mathrm{A}_{610} \mathrm{~nm}\right)$. The fungal inoculums Candida albicans, Trichoderma viride were prepared from 5 to 10 day old culture grown on Potato dextrose agar medium. The Petri dishes were flooded with 8 to 10 $\mathrm{ml}$ of distilled water and the conidia were scraped using sterile spatula. The spore density of each fungus was adjusted with spectrophotometer $\left(\mathrm{A}_{595} \mathrm{~nm}\right)$ to obtain a final concentration of approximately $10^{5}$ spores $/ \mathrm{ml}$.

\subsubsection{Antibacterial Activity [12]}

The in vitro salt callus extracts of $S$. melongena were tested by the well diffusion method. Different concentration of the extracts $(30,60$, and $90 \mu \mathrm{g} / \mathrm{ml})$ was prepared by reconstituting with ethanol and methanol. The test microorganisms were seeded into respective medium by spread plate method $10 \mu \mathrm{l}(10$ cells $/ \mathrm{ml})$ with the $24 \mathrm{~h}$ cultures of bacteria growth in nutrient broth. After solidification the filter paper wells $(5 \mathrm{~mm}$ in diameter) impregnated with the extracts were placed on test organism-seeded plates. Streptomycin $(10 \mu \mathrm{g})$ used as standard for antibacterial test. The antibacterial assay plates were incubated at $37^{\circ} \mathrm{C}$ for $24 \mathrm{hrs}$. The diameters of the inhibition zones were measured in $\mathrm{mm}$.

\subsubsection{Antifungal Activity [13]}

The antifungal activity of ethanol and methanol in vitro salt callus were tested by well diffusion method. The potato dextrose agar plates were inoculated with each fungal culture (10 days old) by point inoculation. The filter paper wells (5 $\mathrm{mm}$ in diameter) impregnated with 20,40 and $60 \mu \mathrm{g} / \mathrm{ml}$ concentrations of the extracts were placed on test organism-seeded plates. Streptocycline (10 $\mu \mathrm{g}$ well 1) used as positive control. The activity was determined after $72 \mathrm{hrs}$ of incubation at $28^{\circ} \mathrm{C}$. The diameters of the inhibition zones were measured in $\mathrm{mm}$.

2.3 Anti-oxidant activity

2.3.1 DPPH Radical Scavenging Activity

DPPH radical is scavenged by antioxidants through the donation of a proton forming the reduced DPPH. The colour change from purple to yellow after reduction can be quantified by its decrease in absorbance at wavelength $517 \mathrm{~nm}$ [14]. Various concentrations of ethanol and methanol extracts of the sample $(0.52 .5 \mathrm{mg} / \mathrm{ml})$ were mixed with $1.0 \mathrm{ml}$ of ethanolic and methanolic solution containing DPPH radicals, resulting in the final concentration of DPPH being $0.2 \mathrm{mM}$. The mixture were shaken vigorously and left to stand for $30 \mathrm{~min}$, and the absorbance was measured at $517 \mathrm{~nm}$. Ascorbic acid was used as control. The percentage of inhibition in DPPH radical scavenging activity was calculated as follows

$\%$ Inhibition $=\mathrm{A}_{0^{-}} \mathrm{A}_{1} / \mathrm{A}_{0} \mathrm{X} 100$.

\subsection{2 $\mathrm{ABTS}^{+}$Radical scavenging activity}

$\mathrm{ABTS}^{+}$decolourisation assay involves the generation of the $\mathrm{ABTS}^{+}$chromophore by the oxidation of $\mathrm{ABTS}^{+}$with potassium persulphate. It is applicable for both hydrophilic and lipophilic compounds. The scavenging activity of the leaf extracts on $\mathrm{ABTS}^{+}$radical cation was measured at $734 \mathrm{~nm}[15]$.

$\mathrm{ABTS}^{+}$solution: Equal volume of $7 \mathrm{mM}$ of $\mathrm{ABTS}^{+}$was mixed with $2.45 \mathrm{mM}$ potassium persulphate and the mixture was allowed to stand in the dark at room temperature for 12-16 hours before use. $\mathrm{ABTS}^{+}$solution was diluted to an absorbance of $0.7 \pm 0.05$ with ethanol and methanol $734 \mathrm{~nm}$. The reaction was initiated by the addition of $1.0 \mathrm{ml}$ of diluted $\mathrm{ABTS}^{+}$to $10 \mu 1$ of different concentrations $(50-250 \mu \mathrm{g} / \mathrm{ml})$ of leaf extract and also to $10 \mu 1$ of ethanol and methanol as control. Ascorbic acid was used as positive control. The absorbance was read at $734 \mathrm{~nm}$ after 6 minutes and the percentage inhibitions were calculated. The inhibition was calculated according to the equation,

$$
\mathrm{I}=\mathrm{A}_{0}-\mathrm{A}_{1} / \mathrm{A}_{0} \times 100,
$$

Where, $A_{0}$ is absorbance of control reaction, $A_{1}$ is absorbance of test compound.

\section{RESULTS}

3.1 Antimicrobial activity

The antimicrobial activity of ethanolic and methanolic extracts of S. melongena salt callus against various microbial strains with respect to various concentrations $(30-90 \mu \mathrm{g} / \mathrm{ml})$ were presented in the table 1 . In $S$. melongena salt callus ethanolic extract, the zone of inhibition of test concentrations were compared with standard concentration of control (Streptocycline 10 $\mu \mathrm{g} / \mathrm{ml})$. Plate. 1A, B, C, and D shows significant result of different concentration of extract and the control. Among the four different bacteria used (E.coli,K. pneumonia,S. 
aureus, $S$. pyogenes) in the case of E.coli the zone of inhibition is higher $(13.60 \pm 0.20 \mathrm{~mm})$ in $90 \mu \mathrm{g} / \mathrm{ml}$ concentration (Plate. 1A) against the control $(08.50 \pm 0.17$ $\mathrm{mm} 10 \mu \mathrm{g} / \mathrm{ml}$ ), followed by $60 \mu \mathrm{g} / \mathrm{ml}$ concentration $(09.66 \pm 0.17 \mathrm{~mm})$. In the case of $S$. aureus the zone of inhibition is higher in $90 \mu \mathrm{g} / \mathrm{ml}$ concentration $(12.70 \pm 0.17 \mathrm{~mm})$ against its control $(10 \mathrm{~mm} / 10 \mu \mathrm{g} / \mathrm{ml})$ (Plate. 1C) followed by $60 \mu \mathrm{g} / \mathrm{ml}$ concentration $(07.66 \pm 0.14 \mathrm{~mm})$. In $K$. pneumonia also the maximum inhibition zone $(11.83 \pm 0.12 \mathrm{~mm})$ was observed in 90 $\mu \mathrm{g} / \mathrm{ml}$ concentration followed by $60 \mu \mathrm{g} / \mathrm{ml}(06.56 \pm 0.26$ $\mathrm{mm})$ (Plate. 1B) against the control $(07.50 \pm 0.23 \mathrm{~mm})$. At $90 \mu \mathrm{g} / \mathrm{ml}$ of concentration the zone of inhibition is higher $(09.56 \pm 0.14 \mathrm{~mm})$ followed by $60 \mu \mathrm{g} / \mathrm{ml}$ concentration $(06.56 \pm 0.20 \mathrm{~mm})$ in $S$. pyogenes against control $(10.53 \pm 0.20 \mathrm{~mm})$ (Plate. 1D, Table 1).

In methanolic extract among the four different bacteria used, in the case of $S$. aureus the zone of inhibition is higher in $90 \mu \mathrm{g} / \mathrm{ml}$ concentration $(12.63 \pm 0.14 \mathrm{~mm})$ against its control $(10 \mathrm{~mm} / 10 \mu \mathrm{g} / \mathrm{ml})$ (Plate. 2C) followed by $60 \mu \mathrm{g} / \mathrm{ml}$ concentration $(07.50 \pm 0.20 \mathrm{~mm})$. In the case of E.coli the zone of inhibition is higher $(12.50 \pm 0.17 \mathrm{~mm})$ in $90 \mu \mathrm{g} / \mathrm{ml}$ concentration (Plate. $2 \mathrm{~A}$ ) against the control $(8.73 \pm 0.08 \mathrm{~mm} 1 \mu \mathrm{g} / \mathrm{ml})$, followed by $60 \mu \mathrm{g} / \mathrm{ml}$ concentration $(8.46 \pm 0.14 \mathrm{~mm})$. In $K$. pneumonia also the maximum inhibition zone $(12.13 \pm 0.26 \mathrm{~mm})$ was observed in $90 \mu \mathrm{g} / \mathrm{ml}$ concentration followed by $60 \mu \mathrm{g} / \mathrm{ml}$ $(8.53 \pm 0.12 \mathrm{~mm})$ (Plate. 2B) against the control $(8.80 \pm 0.11 \mathrm{~mm})$ respectively. At $90 \mu \mathrm{g} / \mathrm{ml}$ of concentration the zone of inhibition is higher $(11.23 \pm 0.23$ $\mathrm{mm})$ followed by $(8.63 \pm 0.17 \mathrm{~mm})$ at $60 \mu \mathrm{g} / \mathrm{ml}$ in $S$. pyogenes against control $(10.63 \pm 0.14 \mathrm{~mm})$ (Plate. 2D, Table 1).

The human fungal pathogens like Candida albicans and Trichoderma viride, the zone of inhibition was observed in ethanolic extracts of salt callus compared with standard drug and presented in Table 1. Among the two different fungal used, in the case of $C$. albicans the zone of inhibition is higher $(8.63 \pm 0.21 \mathrm{~mm})$ in $90 \mu \mathrm{g} / \mathrm{ml}$ concentration (Plate. 1E) against the control $(8.63 \pm 0.12$ $\mathrm{mm} 1 \mu \mathrm{g} / \mathrm{ml})$, followed by $60 \mu \mathrm{g} / \mathrm{ml}$ concentration $(5.66 \pm 0.24 \mathrm{~mm})$. In the case $T$. viride the zone of inhibition is higher in $90 \mu \mathrm{g} / \mathrm{ml}$ concentration $(6.80 \pm 0.15$ $\mathrm{mm})$ against its control $(8.70 \pm 0.15 \mathrm{~mm} / 10 \mu \mathrm{g} / \mathrm{ml})$ (Plate. $1 \mathrm{~F})$ followed by $60 \mu \mathrm{g} / \mathrm{ml}$ concentration $(5.56 \pm 0.08 \mathrm{~mm})$. In methanolic extracts $C$. albicans the zone of inhibition is higher $(8.73 \pm 0.21 \mathrm{~mm})$ in $90 \mu \mathrm{g} / \mathrm{ml}$ concentration (Plate.2E, Table 1) against the control $(8.43 \pm 0.23$ $\mathrm{mm} 10 \mu \mathrm{g} / \mathrm{ml})$, followed by $60 \mu \mathrm{g} / \mathrm{ml}$ concentration $(5.56 \pm 0.26 \mathrm{~mm})$. In the case $T$. viride the zone of inhibition is higher in $90 \mu \mathrm{g} / \mathrm{ml}$ concentration $(8.56 \pm 0.24$ $\mathrm{mm})$ against its control $(7.76 \pm 0.18 \mathrm{~mm} / 10 \mu \mathrm{g} / \mathrm{ml})$ (Plate. $2 \mathrm{~F})$ followed by $60 \mu \mathrm{g} / \mathrm{ml}$ concentration $(4.53 \pm 0.21 \mathrm{~mm})$. 3.2 Antioxidant activity

3.2.1DPPH activity

The antioxidant activities of Solanum melongena ethanolic and methanolic $\mathrm{NaCl}$ salt derived callus extracts were assessed by using DPPH and ABTS activity. The DPPH activity of different concentration of solvent extracts $(1 \mathrm{mg} / \mathrm{ml}$ to $5 \mathrm{mg} / \mathrm{ml}$ ) along with standard ascorbic acid is presented in the table 2. Among the five different concentration $(50 \mu \mathrm{g} / \mathrm{ml}$ to $250 \mu \mathrm{g} / \mathrm{ml})$ of extracts tested, the higher percentage of inhibition (52.25 \pm 0.41 ) was observed in $250 \mu \mathrm{g} / \mathrm{ml}$ of methanolic extract followed by ethanolic extract $(50.30 \pm 0.28)$, against the standard ascorbic acid (61.53 \pm 0.11$)$ (Fig.1). The minimum DPPH activity $6.34 \pm 0.09$ and $8.12 \pm 0.40$ was noticed in $50 \mu \mathrm{g} / \mathrm{ml}$ concentration of ethanolic and methanolic extract respectively. The dose titration curves allowed determination of $\mathrm{IC}_{50}$ for the ethanolic and methanolic callus extracts towards DPPH scavenging activity. The extracts demonstrated dose dependent DPPH scavenging activity effects with IC $_{50}$ values $248.50 \mu \mathrm{g} / \mathrm{ml}$, $239.23 \mu \mathrm{g} / \mathrm{ml}$ and $203.15 \mu \mathrm{g} / \mathrm{ml}$ in ethanolic, methanolic extracts and standard ascorbic acid respectively (Fig. 1). The result showed that the both ethanolic and methanolic extracts possess almost similar potent scavenging activity of the stable free radical DPPH.

3.2.2 $\mathrm{ABTS}^{+}$Scavenging Assay

ABTS $^{+}$activity of ethanolic and methanolic extracts of $S$. melongena $\mathrm{NaCl}$ salt stressed callus were assayed by using five different concentrations $(50 \mu \mathrm{g} / \mathrm{ml}$ to 250 $\mu \mathrm{g} / \mathrm{ml})$. The result of the percentage of inhibition solvent extracts is presented in table 3 and figure 4 . The absorbance was increased with the increasing concentrations of both methanolic and ethanolic callus extracts. In this study more inhibition (59.25 0.49 and $54.90 \pm 0.54)$ was observed in the concentration of 250 $\mu \mathrm{g} / \mathrm{ml}$ of methanolic and ethanolic extracts respectively. It is followed by $200 \mu \mathrm{g} / \mathrm{ml}$ concentration with $51.48 \pm 0.69$ and $45.32 \pm 0.14$ inhibition in methanolic and ethanolic extracts respectively, where as in standard ascorbic acid the absorbance was $72.10 \pm 0.47$ in $250 \mu \mathrm{g} / \mathrm{ml}$ concentration and $59.10 \pm 0.20$ in $200 \mu \mathrm{g} / \mathrm{ml}$ concentration (Table 3, Fig. 2). The $\mathrm{IC}_{50}$ values of ethanolic and methanolic extracts determined by the values presented in fig 2 . $\mathrm{IC}_{50}$ values of ethanolic, methanolic and standard ascorbic acid is $227.68 \mu \mathrm{g} / \mathrm{ml}$, $210.97 \mu \mathrm{g} / \mathrm{ml}$ and $169.20 \mu \mathrm{g} / \mathrm{ml}$ respectively (Fig. 2). The inhibition value of methanolic and ethanolic salt induced callus extract was almost equal. 
Table.1: Antimicrobial activity of ethanolic and methanolic extracts of Solanum melongena L. callus

\begin{tabular}{|c|c|c|c|c|c|c|c|c|c|}
\hline \multirow{2}{*}{$\begin{array}{l}\text { S. } \\
\mathbf{N} \\
\text { o }\end{array}$} & \multirow[t]{2}{*}{$\begin{array}{l}\text { Pathogenic } \\
\text { Microbes }\end{array}$} & \multicolumn{3}{|c|}{$\begin{array}{l}\text { Ethanol extract Zone of } \\
\text { inhibition (mm) }\end{array}$} & \multirow{2}{*}{ 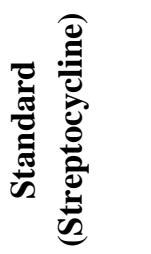 } & \multicolumn{3}{|c|}{$\begin{array}{l}\text { Methanol extract Zone of } \\
\text { inhibition }(\mathbf{m m})\end{array}$} & \multirow{2}{*}{ 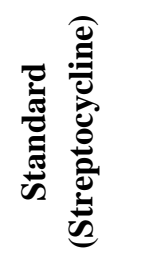 } \\
\hline & & $30 \mu \mathrm{l}$ & $60 \mu \mathrm{l}$ & $90 \mu \mathrm{l}$ & & $30 \mu \mathrm{l}$ & $60 \mu \mathrm{l}$ & $90 \mu \mathrm{l}$ & \\
\hline 1. & $\begin{array}{l}\text { Escherichia } \\
\text { coli }\end{array}$ & $\begin{array}{c}6.53 \pm 0.2 \\
0\end{array}$ & $\begin{array}{l}9.66 \pm 0.1 \\
7\end{array}$ & $\begin{array}{c}13.60 \pm 0.2 \\
0\end{array}$ & $8.50 \pm 0.17$ & $\begin{array}{c}6.63 \pm 0.2 \\
0\end{array}$ & $\begin{array}{c}8.46 \pm 0.1 \\
4\end{array}$ & $\begin{array}{c}12.50 \pm 0.1 \\
7\end{array}$ & $8.73 \pm 0.08$ \\
\hline 2. & $\begin{array}{c}\text { Klebsiella } \\
\text { pneumoniae }\end{array}$ & $\begin{array}{c}5.56 \pm 0.2 \\
4\end{array}$ & $\begin{array}{c}6.56 \pm 0.2 \\
6\end{array}$ & $\begin{array}{c}11.83 \pm 0.1 \\
2\end{array}$ & $7.50 \pm 0.23$ & $\begin{array}{c}5.66 \pm 0.1 \\
4\end{array}$ & $\begin{array}{l}8.53 \pm 0.1 \\
2\end{array}$ & $\begin{array}{c}12.13 \pm 0.2 \\
6\end{array}$ & $8.80 \pm 0.11$ \\
\hline 3. & $\begin{array}{l}\text { Staphylococc } \\
\text { us aureus }\end{array}$ & $\begin{array}{c}6.76 \pm 0.1 \\
4\end{array}$ & $\begin{array}{c}7.66 \pm 0.1 \\
4\end{array}$ & $\begin{array}{c}12.70 \pm 0.1 \\
7\end{array}$ & $\begin{array}{c}10.46 \pm 0.1 \\
4\end{array}$ & $\begin{array}{c}6.46 \pm 0.1 \\
7\end{array}$ & $\begin{array}{l}7.50 \pm 0.2 \\
0\end{array}$ & $\begin{array}{c}12.63 \pm 0.1 \\
4\end{array}$ & $\begin{array}{c}10.53 \pm 0.2 \\
0\end{array}$ \\
\hline 4. & $\begin{array}{c}\text { Streptococcus } \\
\text { pyogenes }\end{array}$ & $\begin{array}{c}5.46 \pm 0.1 \\
7 \\
\end{array}$ & $\begin{array}{c}6.56 \pm 0.2 \\
0 \\
\end{array}$ & $9.56 \pm 0.14$ & $\begin{array}{c}10.53 \pm 0.2 \\
0 \\
\end{array}$ & $\begin{array}{c}6.40 \pm 0.1 \\
5 \\
\end{array}$ & $\begin{array}{c}8.63 \pm 0.1 \\
7 \\
\end{array}$ & $\begin{array}{c}11.23 \pm 0.2 \\
3 \\
\end{array}$ & $\begin{array}{c}10.63 \pm 0.1 \\
4 \\
\end{array}$ \\
\hline 5. & $\begin{array}{l}\text { Candida } \\
\text { albicans }\end{array}$ & $\begin{array}{c}3.60 \pm 0.2 \\
6\end{array}$ & $\begin{array}{c}5.66 \pm 0.2 \\
4\end{array}$ & $8.63 \pm 0.21$ & $8.63 \pm 0.12$ & $\begin{array}{c}3.73 \pm 0.2 \\
1\end{array}$ & $\begin{array}{l}5.56 \pm 0.2 \\
6\end{array}$ & $8.73 \pm 0.21$ & $8.43 \pm 0.23$ \\
\hline 6. & $\begin{array}{l}\text { Trichoderma } \\
\text { viride }\end{array}$ & $\begin{array}{c}3.63 \pm 0.2 \\
1\end{array}$ & $\begin{array}{l}5.56 \pm 0.0 \\
8\end{array}$ & $6.80 \pm 0.15$ & $8.70 \pm 0.15$ & $\begin{array}{c}3.53 \pm 0.2 \\
\quad 3\end{array}$ & $\begin{array}{c}4.53 \pm 0.2 \\
1\end{array}$ & $8.56 \pm 0.24$ & $7.76 \pm 0.18$ \\
\hline
\end{tabular}

Plate: 1 Antimicrobial activity of ethanolic extract of Solanum melongena
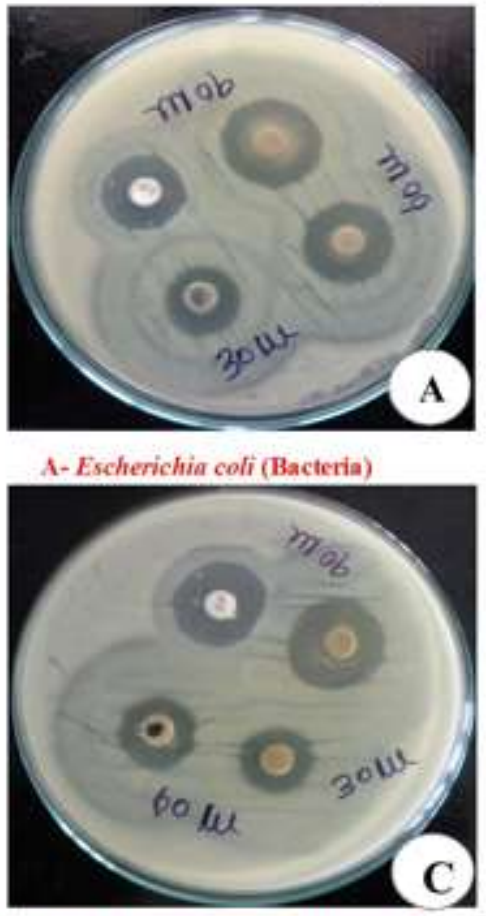

C. Staphylococcus aureus (Bacteria)

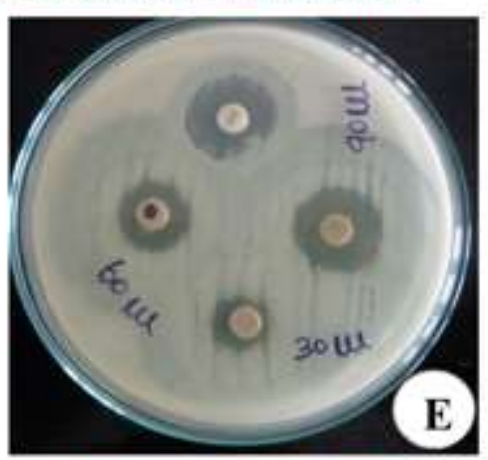

E- Candida albicans (Fungi)

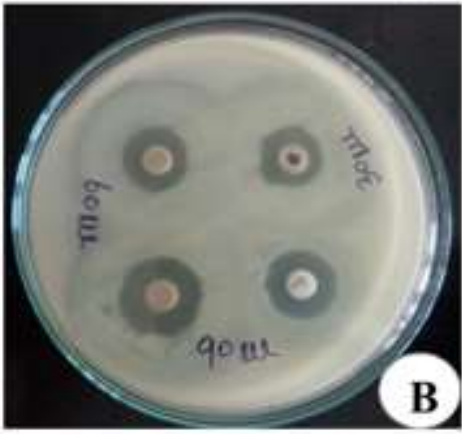

B- Klebsiella pnemoniae (Bacteria)

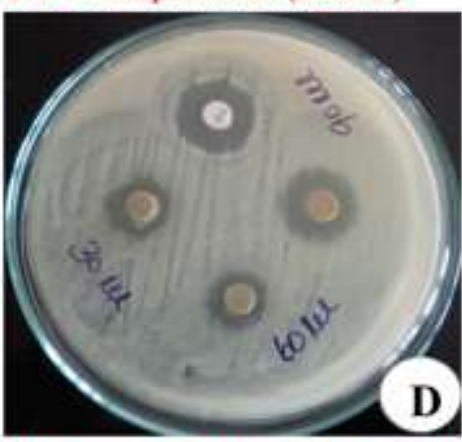

D- Streptococcus pyogenes (Bacteria)

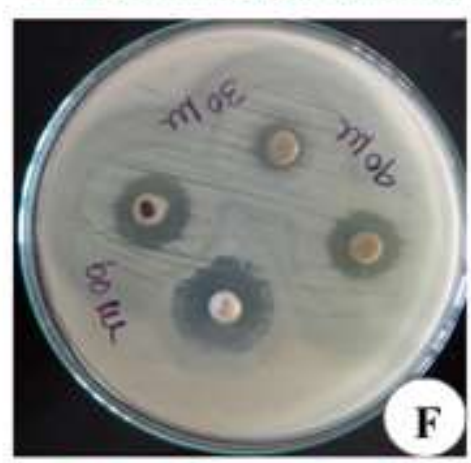

F- Trichoderma viride (Fungi) 
Plate 2-Antimicrobial activity of methanolic extract of Solanum melongena

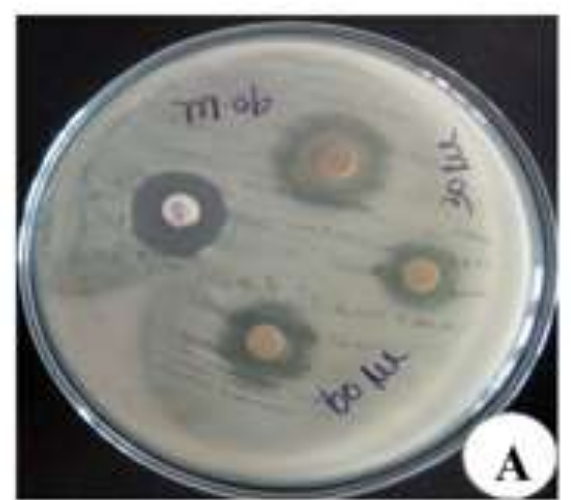

A- Escherichia coli (Bacteria)

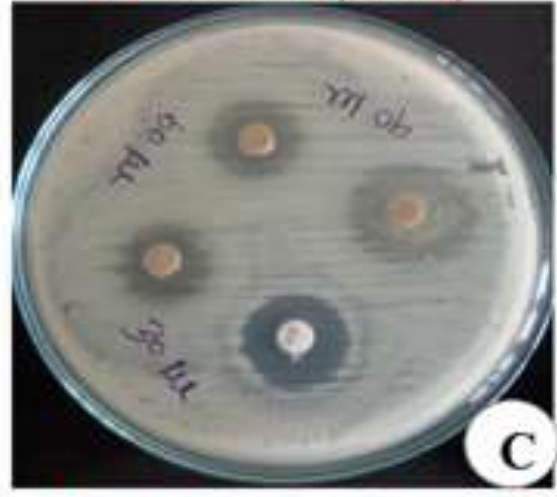

C-Staplydacoceas aureas (Bacteria)

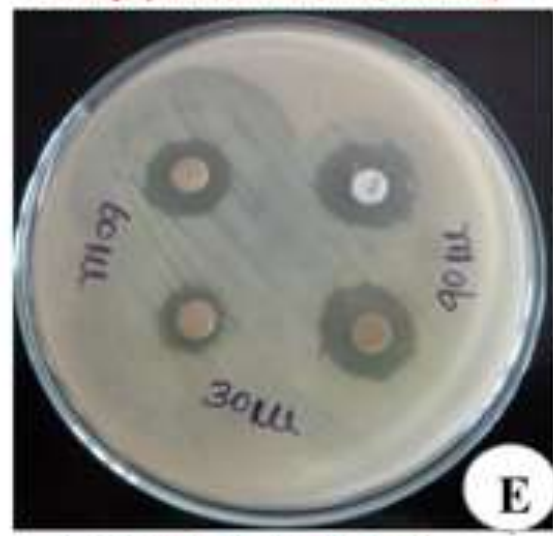

E- Candida ulbicuns (Fungi)

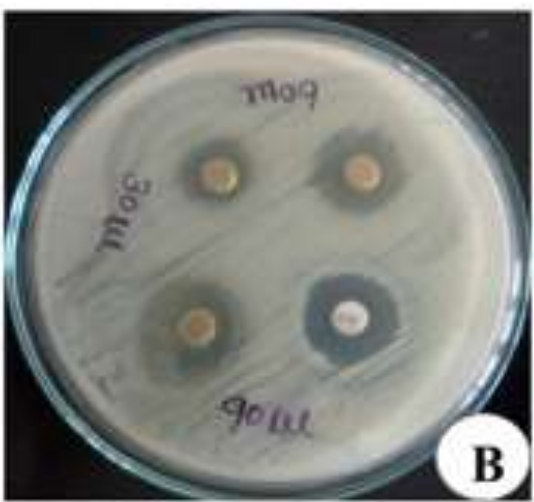

B- Klebsiella pnemoniae (Bacteria)

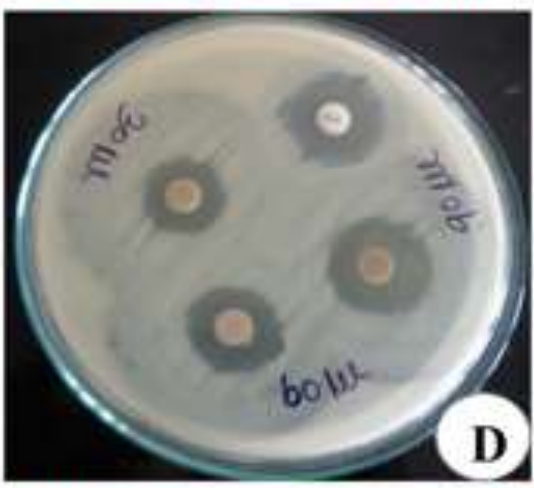

D-Streptococcus pyogenes (Bacteria)

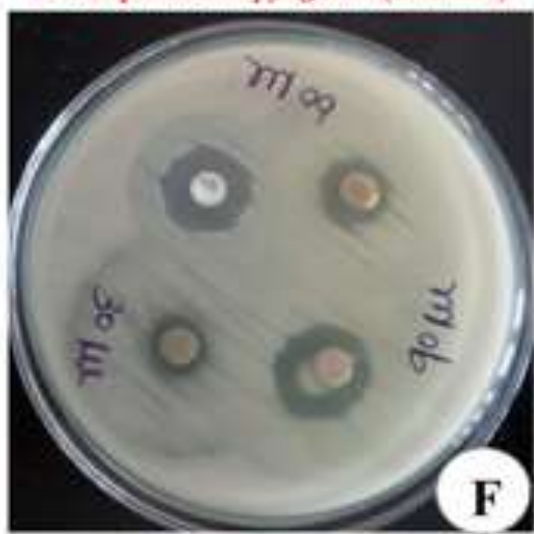

F- Trichodermat viride (Fungi)

Table.2: DPPH activity of different concentration of ethanolic and methanolic leaf callus extracts of Solanum melongena L.

\begin{tabular}{|c|c|c|c|c|c|c|c|}
\hline \multirow{2}{*}{$\begin{array}{c}\text { S. } \\
\text { No. }\end{array}$} & & \multicolumn{5}{|c|}{$\%$ inhibition } & \\
\cline { 3 - 7 } & & $50(\mu \mathrm{g} / \mathrm{ml})$ & $100(\mu \mathrm{g} / \mathrm{ml})$ & $150(\mu \mathrm{g} / \mathrm{ml})$ & $200(\mu \mathrm{g} / \mathrm{ml})$ & $250(\mu \mathrm{g} / \mathrm{ml})$ & $\begin{array}{l}\text { IC } 50 \\
\text { Value }(\mu \mathrm{g} / \\
\mathrm{ml})\end{array}$ \\
\hline 1 & $\begin{array}{c}\text { Ethanol } \\
\text { extract }\end{array}$ & $6.34 \pm 0.09$ & $14.64 \pm 0.37$ & $22.13 \pm 0.38$ & $33.54 \pm 0.61$ & $50.30 \pm 0.28$ & 248.50 \\
\hline 2 & $\begin{array}{c}\text { Methanol } \\
\text { extract }\end{array}$ & $8.12 \pm 0.40$ & $16.19 \pm 0.52$ & $28.67 \pm 0.70$ & $37.29 \pm 0.27$ & $52.25 \pm 0.41$ & 239.23 \\
\hline 3 & $\begin{array}{c}\text { Ascorbic } \\
\text { acid }\end{array}$ & $16.56 \pm 0.15$ & $25.76 \pm 0.92$ & $37.30 \pm 0.58$ & $49.21 \pm 0.20$ & $61.53 \pm 0.11$ & 203.15 \\
\hline
\end{tabular}




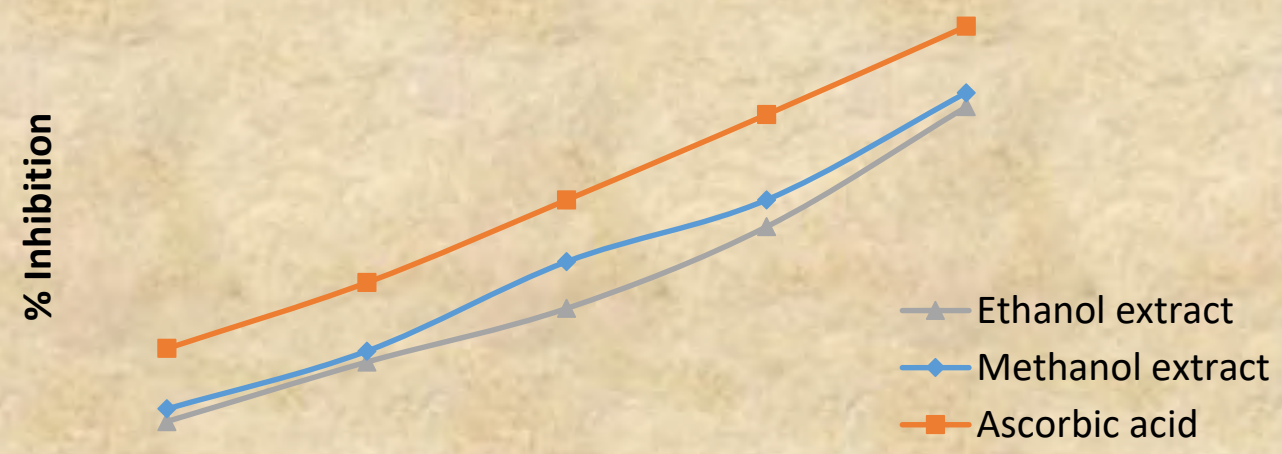

Concentration $(\mu \mathrm{g} / \mathrm{ml})$

Fig.1:DPPH activity of different concentration of ethanolic and methanolic leaf callus extracts of Solanum

$\mathrm{IC}_{50}$ value of Ethanol extract

$\mathrm{IC}_{50}$ value of Methanol extract

$\mathrm{IC}_{50}$ value of Ascorbic acid (standard) melongena $L$.

$: 248.50 \mu \mathrm{g} / \mathrm{ml}$

$: 239.23 \mu \mathrm{g} / \mathrm{ml}$

: $203.15 \mu \mathrm{g} / \mathrm{ml}$

Table.3: ABTS ${ }^{+}$activity of different concentration of ethanolic and methanolic leaf callus extracts of Solanum melongena

\begin{tabular}{|c|c|c|c|c|c|c|c|}
\hline \multirow{2}{*}{$\begin{array}{c}\text { S. } \\
\text { No. }\end{array}$} & & \multicolumn{5}{|c|}{$\%$ inhibition } & \\
\cline { 3 - 8 } & & $50(\mu \mathrm{g} / \mathrm{ml})$ & $100(\mu \mathrm{g} / \mathrm{ml})$ & $150(\mu \mathrm{g} / \mathrm{ml})$ & $200(\mu \mathrm{g} / \mathrm{ml})$ & $250(\mu \mathrm{g} / \mathrm{ml})$ & $\begin{array}{c}\text { IC } 50 \\
\text { Value }(\mu \mathrm{g} / \mathrm{ml})\end{array}$ \\
\hline 1 & $\begin{array}{c}\text { Ethanol } \\
\text { extract }\end{array}$ & $11.99 \pm 0.09$ & $20.61 \pm 0.80$ & $33.85 \pm 0.19$ & $45.32 \pm 0.14$ & $54.90 \pm 0.54$ & 227.68 \\
\hline 2 & $\begin{array}{c}\text { Methanol } \\
\text { extract }\end{array}$ & $14.28 \pm 0.54$ & $26.10 \pm 0.47$ & $39.45 \pm 0.61$ & $51.48 \pm 0.69$ & $59.25 \pm 0.49$ & 210.97 \\
\hline 3 & $\begin{array}{c}\text { Ascorbic } \\
\text { acid }\end{array}$ & $21.45 \pm 0.67$ & $33.39 \pm 0.29$ & $47.71 \pm 0.62$ & $59.10 \pm 0.20$ & $72.10 \pm 0.47$ & 169.20 \\
\hline
\end{tabular}

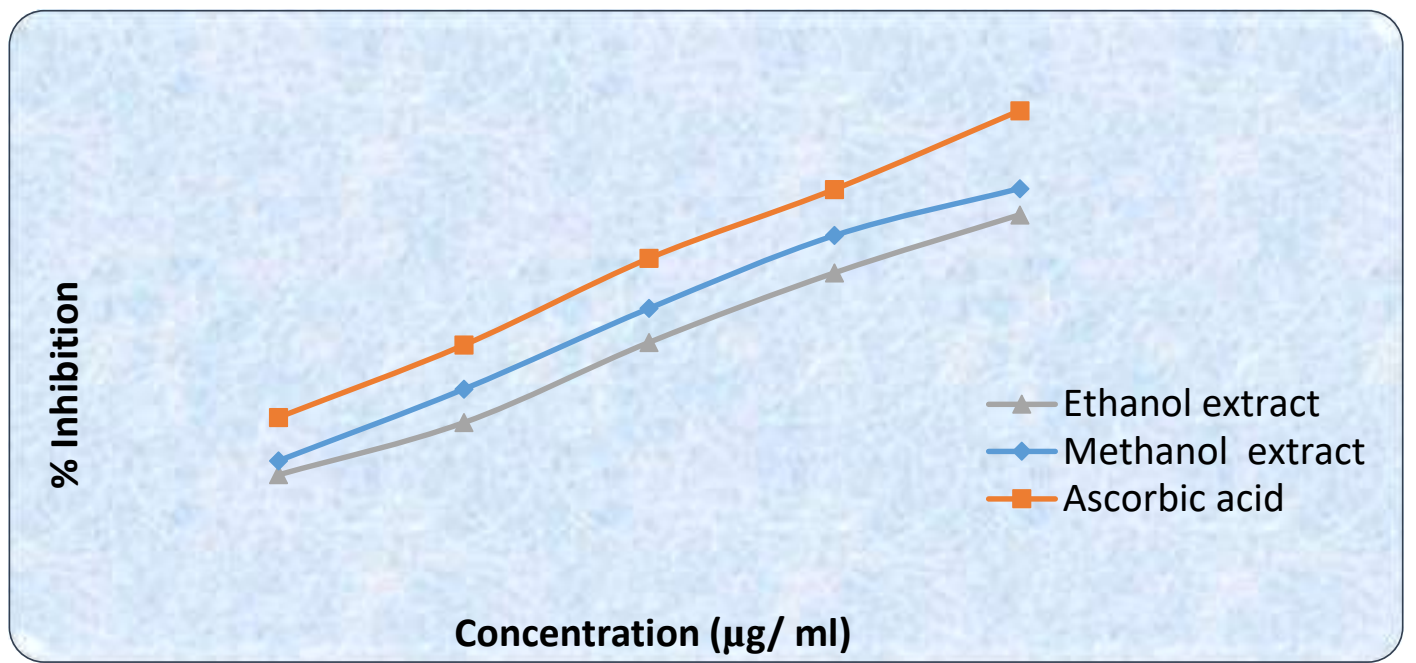

Fig.2: ABTS ${ }^{+}$activity of different concentration of ethanolic and methanolic leaf callus extracts of Solanum
$\mathrm{IC}_{50}$ value of Ethanol extract melongena
$\mathrm{IC}_{50}$ value of Methanol extract
$: 227.68 \mu \mathrm{g} / \mathrm{ml}$
$: 210.97 \mu \mathrm{g} / \mathrm{ml}$
$\mathrm{IC}_{50}$ value of Ascorbic acid (standard)
: $169.20 \mu \mathrm{g} / \mathrm{ml}$ 


\section{DISCUSSION}

Plants are employed as important source for traditional medications [16]. It is important to study scientifically, plants that have been used in traditional medicines to determine potential sources of novel antimicrobial compounds [17]. Secondary metabolites like alkaloids, glycosides, steroids, flavonoids are potential sources of drugs present in medicinal plants.Moreover the natural antioxidants including carotenoids, flavonoids, cinnamic acids, benzoic acids, folic acid, ascorbic acid, tocopherols and tocotrienols are the secondary metabolites produced by plants for their sustenance. The bioactive substances like Beta-carotene, ascorbic acid and alpha tocopherolare the free radical scavengers with enhanced potential. Natural antioxidants are the vegetables play a significant role in reducing the risk of certain types of cancer, cardiovascular diseases and other chronic diseases [18]. The question of subjecting medicinal herbs to modern scientific test has often been raised. Biosynthesis of secondary metabolites is affected strongly by salt stress resulting in considerable fluctuations in quality and quantity.

Production of secondary metabolites by callus culture have made it possible for the increased yield of a wide variety of pharmaceuticals such as alkaloids, terpenoids, steroids, saponins, phenolics, and flavonoids [19]. Environmental stresses strongly influence plant growth and development. Salinity is one of the most important of these stresses and can limit crop yield [20]. Today, 20\% of the World's cultivated land and nearly half of all irrigated lands are affected by salinity [21]. Salt stress has become one of the most damaging environmental hazards to crop productivity all over the world [22].

The cultivation of medical plants using different growth regulators to enhance the production of bioactive compounds is required for commercial and research application. Bioactive compounds were found to be accumulating in culture cells at higher level than those in natural plants though optimization of culture conditions [23]. Free proline and phenol increased exponentially with the increase in $\mathrm{NaCl}$ level was reported in Solanum nigrum[24].

Antimicrobial effects of ethanolic and methanolic extracts salt callus of $S$. melongena showed good antimicrobial activities against human pathogens. Whereas another reports observed in the leaves of eggplant had antibacterial activity on gram negative only [25]. Whereas, the methanol extract of S. melongena seed gave maximum inhibition against Staphylococcus aureus and Escherichia coli. It is quite obvious that the inhibition level gradually increases in accordance with the level of increase in concentration. Similar observation also found in our results. However, in contrary same methanolic extract of S. melongena seed did not have any inhibitory activity against Pseudomonas aeruginosaand Proteus vulgaris [26].

The steroidal glycoalkaloids are the family of secondary metabolites produced by Solanaceous plants, including potato, tomato and eggplant[27]. Steroidal glycoalkaloids have antimicrobial, insecticidal and fungicidal properties which provide resistance against several insect pests and herbivores[28]. In the present study both the extracts showed good antimicrobial activity. This may be due to the presence of glycoalkaloids present in this family.

In addition to the support our results the mangrove (salt watered growing) plant Avicennia marina extracts showed good antimicrobial activity against E. coli, S. aureus, and B. subtilis. The result of present study for antibacterial activity agrees with leaf extract of mangrove plants[29,30,31]. Our reports revealed that the salt stressed $S$. melongena callus extracts shows more antimicrobial activity compared with normal brinjal plant extracts[32].

The DPPH radical were used to study the scavenging activity of some natural compounds. The results of scavenging DPPH radical ability of $S$. melongena at different concentration in comparison with standard ascorbic acid showed in the figure 1. In DPPH scavenging activity assay the $\mathrm{IC}_{50}$ value of ethanolic, methanolic and ascorbic acid was $248.50 \mu \mathrm{g} / \mathrm{ml}, 239.23 \mu \mathrm{g} / \mathrm{ml}$ and 203.15 $\mu \mathrm{g} / \mathrm{ml}$ respectively. The extracts of $S$. melongenashowed dose dependent DPPH radical scavenging activity. These findings shows that there is a strong relationship between the secondary metabolites and antioxidant activity of plant materials. Our findings are comparable with earlier reports of S. melongenain vivo plant extracts[33] and $S$. surathense leaf extract [34]. The DPPH scavenging activity antioxidants is due to the reaction between antioxidant molecules and radical, which occur by donating the hydrogen during the scavenging of the radical. Ourin vitro callus extract results were comparable that of in vivo plant extract of $S$. melongenaand S.surathense[33,34].

The decolorization of $\mathrm{ABTS}^{+}$cation radical is a way to measure the antioxidant activity of extracts. Positive correlation between phenolic content and antioxidant activity was reported by Awikaet.al. 2003[35]. Polyphenols are the major plant compounds with antioxidant activity. The activity of phenolic compounds is mainly due to their redox properties[36,37]which can do an main role in free radical absorbing and neutralizing, singlet and triplet oxygen quenching or peroxides decomposing. Result of the present study revealed that ethanolic and methanolic extracts possess superior antioxidant activities. Alcoholic extracts of $S$. melongena showed potent ABTS radical scavenging activity with $\mathrm{IC}_{50}$ value of 227.68 and $210.97 \mu \mathrm{g}$ respectively. Many scientists reported the presence of steroids, terpenoids, 
flavonoids, phenolic compounds, tannins in various extracts of S. melongena[38,39,40,41]. These reports confirmed that both ethanolic and methanolic extracts showed high level of antioxidant activity in in vitro system.

\section{CONCLUSION}

The presence of various bioactive compounds in the both ethanolic and methanolic extracts of salt stressed callus of $S$. melongena justifies that, the salt stress have been induced to produce strong bioactive compounds. However, isolation of individual phytochemical constituents and subjecting it to the biological activity from salinity tolerance callus will definitely give fruitful results. The results, shows that the salt stressed $S$. melongena callus contains various bioactive compounds. Therefore, it is concluded that in vitro clonal propagation with salt stress could alter the biochemical changes which could be a phytopharmaceutically and morphopotencially importance. These reports confirmed that both ethanolic and methanolic extracts showed high level of antimicrobial activity and antioxidant activity in in vitro system.

\section{REFERENCES}

[1] Sathyaprabha G, Kumaravel S, Ruffina D,Praveenkumar P. A comparative study on antioxidant, proximate analysis, antimicrobial activity and phytochemical analysis of Aloe vera and Cissusquadrangularis by GC-MS. J. Pharm Res. 2010;3:2970-73.

[2] Burt S. Essential oils: their antibacterial properties and potential applications in foods, A review. Int $\mathrm{J}$ Food Microbiol.2004;94(3):223-53.

[3] Kim SJ, Cho AR, Han J. Antioxidant and antimicrobial activities of leafy green vegetable extracts and their applications to meat product preservation. Food Control.2013;29:112-20.

[4] Basavaraju R. Plant tissue culture-Agriculture and health of man. Indian J Sci\& Tech.2011; 4(3):33335 .

[5] Khan R.Solanum melongena and its ancestral forms. Hawkes J, Lester R. Skelding A (eds.) In: The Biology and Taxonomy of the Solanaceae. 1979:629-36.

[6] Jorge PA, Neyra LC, Osaki RM, de Almeida E,Bragagnolo N. Effect of eggplant on plasma lipid levels, lipidic peroxidation and reversion of endothelial dysfunction in experimental hypercholesterolemia.Arq BrasCardiol. 1998;70:8791.

[7] Silva ME, Santos RC, O'Leary MC,Santos RS. Effect of aubergine (Solanum melongena) on serum and hepatic cholesterol and triglycerides in rats. Braz Arch Biol Tech. 1999;42:339-42.

[8] Igarashi K, Yoshida T, Suzuki E. Antioxidative activity of nasunin in choujanasu (little eggplant, Solanum melongena L. Chouja). J JpnSoc Food Sci. 1993;40:138-43.

[9] Noda Y, Kneyuki T, Igarashi K, Mori A, Packer L. Antioxidant activity of nasunin, an anthocyanin in eggplant.Res

CommunMolPatholPharmacol.1998;102:175-87.

[10] Yoshikawa K, Inagaki K, Terashita T, Shishiyama J, Kuo S,Shankel DM. Antimutagenic activity of extracts from Japanese eggplant.Mutat Res Genet Toxicol Test.1996a;371:65-71.

[11] Gafner S, Woffender JL, Nianga M,Hostettmann K. Phytochemistry.1998;48:215.

[12] Anonymous.Pharmacopiea of India (The Indian Pharmacopiea). $3^{\text {rd }}$ Edn, Govt of India. New Delhi. Ministry of Health and Family Welfare. 1996.

[13] Taylor RSL, Manandhar NP, Hudson JB,Towers GHN. Screening of selected medicinal plants of Nepal for antimicrobial activities,.JEthnopharma. 1995;546:153-59.

[14] Shimada K, Fujikawa K, Yahara K, Nakamura T. Antioxidative properties of xanthan on the autoxidation of soybean oil in cyclodextrin emulsion. JAgric Food Che. 1992;40:945-48.

[15] Giao MS, Gonzalez SML, Rivero PMD, Pereira CI, Pintado ME,Malcata FX. Infusions of Portuguese medicinal plants. Dependence of final antioxidant capacity and phenolic content on extraction features. J Sci Food Agri. 2007;87:2638-47.

[16] Neves JM, Matos C, Moutinho C, Queiroz G, Gomes LR.Ethnopharmacological notes about ancient uses of medicinal plants in Tras-os-Montes (northern of Portugal). J. Ethnopharm. 2009;124(2):270-83.

[17] Hammer KA, Carson C, Riley T. Antimicrobial activity of essential oils and other plant extracts.J AppliMicrobio.2001; 86(6):985-90.

[18] Ajila CM, Naidu KA, Bhat SG, Prasada RU, Rao JS. Bioactive compounds and antioxidant potential of mango peel extract. Food Che.2007;105:982-88.

[19] Ramachandra RS,Ravishankar GA. Plant cell cultures: chemical factories of secondary metabolites. Biotech Adv.2002;20:101-53.

[20] Koca H, Bor M,Ozdemir F. The effect of salt stress on lipid peroxidation, antioxidative enzymes and proline content of sesame cultivars.Environ Exp Bot.2007;60:344-51.

[21] George Daye Mandy C, Waribo Helen Anthony,Okpara Kingsley. Detection of antimicrobial and antimycotic activities of African garden egg fruits (S.melongenaL.) against pathogenic organisms in solvents of varying 
polarities. Scholars Research Library. 2014;6(6):443-47.

[22] Rhoades JD, Loveday J. Salinity in irrigated agriculture. In American Society of Civil Engineers. Irrigation of Agricultural Crops.American Society of Agronomists.1990;2:1089-42.

[23] Mulabagal V, Lee CY, Shu-Fung L, Satish MN, Chien YL,et al,. Studies on the production of some important secondary metabolites from medicinal plants by plant tissue cultures. Bot Bull Acad Sin.2004; 45:1-22.

[24] Santhi M,Muthulakshmi S, Gurulakshmi G,Rajathi S.Effect of salt stress on physiological and biochemical characteristics in Solanum nigrum L. Int J Sci\& Res. 2013;6:14.

[25] Saraf P, Suva RS. Comparison of antimicrobial efficacy of ginger and eggplant leaves against clinical isolates of diabetic foot ulcers. General Practitioner.2009; 17(1): 7-9.

[26] Amutha S. Screening of antibacterial activity of Solanum melongena seed extracts on selected human pathogenic bacteria. Int J Pharm Bio Sci.2014; 5(4):208-13.

[27] Kent FM, Louise VT, Paul VA, Malendia MM, David RR, Dennis LC,et. al,. Metabolic compensation of steroidal glycoalkaloid biosynthesis in transgenic potato tubers: using reverse genetics to confirm the in vivoenzyme function of a steroidal alkaloid galactosyltransferase.Plant Sci. 2004;168(1):267-73.

[28] Rodriguez-Saona LE, Wrolstad RE, Pereira C.Glycoalkaloid content and anthocyanin stability to alkaline treatment of red fleshed potato extracts.J Food Sci.1999;64(3):445-50.

[29] Imdadul H, Wirakarnain S, Koshy P, Arash R, Shariff HABM, Mat TR. Valuable antioxidant and antimicrobial extracts from Rhizophoramucronataof Asiatic mangrove forests.Res J Biotech.2011a;6(1):10-14.

[30] Natarajan V, Venugopal P, Menon T. Effect of Azadirachta indica (Neem) on the growth pattern of dermatophytes.Indian J Med Micro bio.2003;21(2):98-101.

[31] Imdadul H, Wirakarnain S, Shariff HABM, Mat TR,Monneruzzaman KM. Total phenolic contents, antioxidant and antimicrobial activities of Bruguieragymnorrhiza.J Med Plant Res.2011b;5(17): 4112- 18.

[32] Ashraf M, Ali Q. Relative membrane permeability and activities of some antioxidant enzymes as the key determinants of salt tolerance in canola (Brassica napusL.).Environ Exp Bot. 2008;63: 26673.
[33] Bushra Sultana, ZaibHussain, Munazza Hameed, Muhammad Mustaq. Antioxidant activity among different parts of Aubergine (Solanum melongena $\mathrm{L}$. ). Pak J Bot.2013;45(4):1443-48.

[34] SrideviMuruhan, SenthilSelvaraj, PugalendiKodukkurViswanathan. In vitro antioxidant activities of Solanum surattense leaf extract. A Pacific J TropiBiomedi.2013;3(1): 28-34.

[35] Awika JM, Roony LM, Wu X, Prior RL,Zevallos LC. Screening methods to measure antioxidant activity of Sorghum (Sorghum bicolor) and sorghum products. J Agri Food Che. 2003;51:6657-62.

[36] Galato D, Ckless K, Susin MF, Giacomelli C, Ribeiro-do-Valle RM,Spinelli A. Antioxidant capacity of phenolic and related compounds, correlation among electrochemical, visible spectroscopy methods and structure-antioxidant activity. Redox Report. 2001;6(4):243-50.

[37]Zheng W, Wang SY. Antioxidant activity and phenolic compounds in selected herbs. J Agri Food Che.2001;49:5165-70.

[38] Anushree Tiwari, Rajesh, Jadon S, Piyush Tiwari,Nayak S. Phytochemical investigations of crown of Solanum melongena fruit.Int J Phytomedi. 2009;1:9-11.

[39] Kwon YI, Apostolidis E, Shetty K.In vitro studies of eggplant (Solanum melongena) phenolics as inhibitors of key enzymes relevant for type 2 diabetes and hypertension.Bioresour Tech.2008; 99(8):2981 - 88.

[40] Loredana Salerno, Maria N, Modica, Valeria Pittalà, Giuseppe Romeo, Maria A,Siracusa, Claudia Di Giacomo, Valeria Sorrenti, Rosaria acquaviva. Antioxidant activity and phenolic content of microwave-assisted Solanum melongena extracts. Sci World J.2014;1:1-6.

[41] Ghoson Saleh S. Chemical detection of some active compounds in eggplant (Solanum melongena) callus as compared with fruit and root contents.Int J Curr Microbio App Sci.2015;4(5):160-65. 